\title{
Evaluation of meal supervision for patients attending an eating disorders day program
}

\author{
Lisa Herbert, Jessica Wheatley*, Susan Hart \\ From 2014 ANZAED Conference: Driven Bodies Driven Brains \\ Fremantle, Australia. 22-23 August 2014
}

\section{Background}

Supervision of meals is an essential part of intensive eating disorder treatment. However, there is a lack of evidence regarding the most effective approach when delivering this service. This study evaluated an eating disorder day program's core components of meal supervision against set criteria, and how meal supervision was received by patients.

\section{Methods}

All staff of an eating disorders day program were observed completing meal supervision by an external assessor over a three week period. An audit tool was developed using the program's established mealtime guidelines. Descriptive feedback was sought to evaluate the patients' experience.

\section{Results}

One hundred percent of meals assessed were completed within program guidelines and done so consistently by all staff. Staff commonly used time and behaviour prompts. They explained meal guidelines inconsistently, but as deemed necessary. Staff were more confident with food than fluid guidelines. Patients valued autonomy and less support as they progressed in treatment.

\section{Conclusion}

Day program staff were compliant with the program's mealtime guidelines and were consistent when doing so. Meal supervision was regarded as a positive aspect of treatment, and patients valued meal support being tapered as they advanced.

This abstract was presented in the Service Initiatives stream of the 2014 ANZAED Conference.

* Correspondence: jessica.wheatley@sswahs.nsw.gov.au Derwent House Day Program, Sydney, Australia
Published: 24 November 2014

doi:10.1186/2050-2974-2-S1-O22

Cite this article as: Herbert et al.: Evaluation of meal supervision for patients attending an eating disorders day program. Journal of Eating Disorders 2014 2(Suppl 1):022.
Submit your next manuscript to BioMed Central and take full advantage of:

- Convenient online submission

- Thorough peer review

- No space constraints or color figure charges

- Immediate publication on acceptance

- Inclusion in PubMed, CAS, Scopus and Google Scholar

- Research which is freely available for redistribution
() Bïomed Central 